\title{
Promotion of Family Reading in the Context of Children's Early Reading Literacy Development
}

\author{
Viola Tamášová - Zuzana Šulganová*
}

\begin{abstract}
The proposed study deals with early reading literacy development of pre-school age children. A special attention is paid to the promotion of reading in family environment. Children's relationship to reading starts developing before entering school, therefore, we consider families, alongside with intentional reading development in kindergartens, to be the basic indicators of the development of children's relationship to reading and to books in general. The results of our quantitative research reflect the current situation in reading literacy development of pre-school age children in Slovakia, in particular families, and from the point of view of both the participating parents and their children.
\end{abstract}

Key words: reading and pre-reading literacy, pre-school age, promotion of family reading, spontaneous literacy, early literacy, reading habits.

\section{Introduction}

The notion of literacy as such has recently often been put into relation with preschool age. Research shows that the developmental potential of pre-school age children is specific and sufficient. This means that if it is not being developed, later, it may not be used to its whole extent and this potential could be wasted (Zápotočná, 2011).

It is impossible to define literacy at pre-school age as it is developing spontaneously at this age. We understand reading literacy as the result of the literacy process in which a person has acquired some reading knowledge, skills and competencies and then, subsequently, starts improving them. According to Pazonyi and Bodonyi (2013), facilitating reading (i.e. creating opportunities for it without any pressure to carry out the task) by developing children's

Viola Tamášová, Dubnica Institute of Technology in Dubnica nad Váhom, Dubnica nad Váhom, Slovakia; tamasova@dti.sk

Zuzana Šulganová, Dubnica Institute of Technology in Dubnica nad Váhom, Dubnica nad Váhom, Slovakia; sulganova.zuzana@gmail.com 


\section{Acta Technologica Dubnicae \\ volume 6, 2016, issue 2}

imagination through story-telling, involving them in different actions, and also providing children with texts and pictures to cater the visual types, should be done from as early as possible, maybe even from the last year of pre-schools. At pre-school age, these skills are at the stage of early formation and development, which can be characterised by images, knowledge and some skills acquired before entering formal training at school. From this perspective, we consider the concept of early literacy at pre-school age to be suitable for development. In literature, we can meet the notions of reading pre-literacy, emerging literacy, beginning literacy, pre-reading literacy or, in general, early literacy. In the last years, the concept of early literacy has been gradually replaced by the notion of reading maturity, or preparedness for reading as there is a certain point of time when a child is capable and prepared to start learning to read and write.

Undoubtedly, the environment, in which a child is growing up, represents the basic indicator of its development. Some attitudes that influence one's future orientation and one's adult life start developing in early childhood, i.e. at preschool age, when children spend most of their time in families (Barnová, 2010). We can say the same about the attitudes towards books and the process of reading and writing itself. In the last decades, research has begun to deal with the issues of reading literacy in relation to children's family environment and the reading culture in their families. Dobbs-Oates et al. (2015), Montero et al. (2014), Snow et al. (1997) and Moss and Fawcett (1995) declare that children whose parents practised reading activities with them, read books to them at preschool age, achieve better results in school education than those children whose parents did not read to them and, thus, did not help them create a positive relationship to books (Chandler, 1999). The authors consider such a mutual interaction of parents and children effective in the field of children's reading literacy development as reading to children and talking with them about the text stimulates their imagination, extends children's lexicon, teaches them about the surrounding world, and to work with text.

Many scientific articles, large studies and research emphasize the mutual interrelation of the positive impact of reading to children in families at an early age and their success in the school environment. Tamášová and Šuverová (2008), Kissinger (2004) and Fitzgerald et al. (1991) highlight the mutual relationship between family reading and the school success of a child, too and emphasize the need for reading with children at pre-school age in the family environment. They emphasise the role of a parent as the basic role model for children's early literacy. Indisputably, besides activities supporting elementary understanding and reading, other family activities with children contribute to children's literacy development as well. In their studies, Glazer (1989), Bryant et al. (1990) and Maclean et al. (1987) emphasize the importance of singing songs to children in their family environment, as songs also support the love to 


\section{Acta Technologica Dubnicae \\ volume 6, 2016, issue 2}

language, rhythm, promote phonological consciousness, being a significant predictor of the later literacy development (Chandler, 1999). Kissinger (2004) and Strickland (2004) accentuate the role of adults as basic models for reading literacy development and deal with the nature of a child's thinking development. They recommend parents to have high expectations on the thinking processes of their children. This way they can promote the development of children's lexicon, and, at the same time, a high degree of comprehension of the stories read. Last but not least, with the aim to promote the beginnings of reading, they recommend parents to teach their children to read before they enter the school environment.

Support on the side of the family environment in the field of early literacy development of pre-school age children is of a negligible importance. It enables children to develop reading competencies in a natural, experiential and playful way and to form a basis for their positive relationship to literature at a later age, their reading competencies and reading comprehension.

\section{Methodology}

The first impulse to the realisation of the research was the recognition of the need for the development of children's early reading competencies in family environment, which we consider to be a significant factor influencing the development of a child at pre-school age and the basic determinant of adaptation to the school educational environment. The research problem was formulated into particular research questions closely related to the aims of the research. The main goal of the qualitatively oriented research was to find out the value of the process of reading in family environment in relation to the influence of parents on the development of children's reading literacy, as perceived by parents and their pre-school age children; and to inquire on the intentional and unintentional practices of parents in the process of early reading development at pre-school age. The partial goals of the research were to inquire on the educational methods and means by which parents influence their children's relationship to reading; on various forms of text materials that children are in contact with in their family environment, the family library collection; perception of the process of family reading by pre-school age children; and, last but not least, to analyse and compare the forms of reading activities and of the activities promoting the development of the lexicon that today's parents prefer.

The basic method of collecting research data was a semi-structured interview with parents and children individually. One of our requirements was to realise the interview in the participants' natural family environment, as such kind of observation of the family environment was believed to help us understand the participants' relationships and responses better. During the interviews with the 


\section{Acta Technologica Dubnicae \\ volume 6, 2016, issue 2}

parents and their pre-school age children, we focused on the set framework of questions - semantic categories, that represented the development of pre-school age children's reading competencies in family environment and were created by us. The framework of interview questions and the semantic categories were as follows:

\section{Family model}

- parents' relationship to reading, parents' reading history, grandparents' relationship to reading, the importance of reading in the family, family reading activities, joint reading rituals, children's reading models;

\section{Place of books in a family}

- the place of books in a family, perception of books for children in a family, the place of books in leisure time, the favourite book, the existence of a family library, visiting a library;

\section{Process of reading}

- the concept of reading, reading for the future of children, reading literacy, fiction vs. reality, child reader;

\section{Accompanying activities}

- discussions about the read, children's fantasy development, interactive reading with children, children's identification with storybook characters;

\section{Visual components}

- the content of books for children, the quantity of pictures, the structure of children's books, the design of books for children, other possible ways of the perception of pictures and text.

For a more complex understanding of the importance of family reading for children at pre-school age, we used another method - the method of content analysis of drawings. Gavora (2007) points out the pros of using drawings in qualitative research - in the form of drawings, especially children are able to say what they are not able to express in words. In our interview questions focusing on reading and reading activities in family environment, we motivated and inspired children to complete the drawing task: Draw a picture about how you read fairy tales and storybooks at home. When analysing children's drawings, we focused on the analysis of the common elements that dominated in the children's pictures. They enabled us to find out about the perception of family reading by children at pre-school age in the context of the conditions of their family environment. They were as follows: the place of reading, the context of the environment, children in the role of readers, a close person, the element of literacy, other elements. 


\section{Acta Technologica Dubnicae \\ volume 6, 2016, issue 2}

We worked with a small sample of participants - ten parents (mothers) and their children - intensively and repeatedly. We obtained important data for fulfilling the goals of the research. We adjusted the size of the sample to the quantity of the gathered data. All the mothers had been informed on the organisation and the realisation of the research in advance as well as with the use of the gathered data.

In this study, with the aim to ensure the anonymity of the participants, we do not list their real names. All the persons mentioned in the research have pseudonyms. For a better orientation and differentiation of participants, we use the following labels:

1. pseudonym p. name of the parent - e.g. p. Petra (parent Petra);

2. pseudonym ch. name of the child - e.g. ch. Kristína (child Kristína);

3. pseudonym f. number of the family - e.g. f. 1 (family No. 1).

\section{Results}

The aim of the research was to find out how parents and children at pre-school age perceive the value of the reading process in family environment in relation to parents' influence on children's reading literacy development. We focused on the ways parents (mothers) support their children in the field of developing a positive relationship to reading activities at pre-school age, when reading literacy, as one of one's key competencies, begins. At the same time, the research dealt with the concept of family reading from the children's point of view in a particular family environment.

Based on the subjective responses of the participating mothers and children and their drawings displaying family reading in a particular family environment, we came to the following results:

\section{1 The concept of family reading from the point of view of mothers and their pre-school age children}

When inquiring how mothers and children at pre-school age perceive the concept of family reading, we worked with the subjective responses of mothers and children participating in our research. Based on the approach, motivation and individual experience of the mothers in the field of promoting the development of children's reading literacy and, at the same time, on the preschool age children's attitudes and interests in the elements of literacy and in books as a source of information, we have enriched knowledge in the field of the issues of reading literacy related to family education in the suggested semantic categories as follows: 


\section{Acta Technologica Dubnicae \\ volume 6, 2016, issue 2}

\subsubsection{Family model}

As for the role of the family in the process of developing a child's positive relationship to books, based on the obtained responses, we can point out the importance of support on the side of grandparents. We can state that the influence of grandparents in the given field was evident in family environment (f. 1, 4, 5, 6, 7, 8 and 10). Tough times, heavy workload and lack of time were perceived by mothers as the basic determinants that negatively influenced the situation of joint reading with children, and the need for grandparents' help in bringing up their grandchildren. Mothers experienced a decrease as for their own reading activities in the context of workload and tough times related to the role of a mother and also to the emergence of new information-communication technologies that had a significant impact on the decrease of reading in families. Despite the above mentioned, the joint family reading of the mothers and their children was realised in every participating family, but in various frequency and depth. We can assume that all the participating mothers were aware of their function as an indicator of reading literacy development of their pre-school age children, even in cases when they themselves did not incline to activities related to reading books. The most intense role model of a grandmother, as for reading activities and preferences, could be seen in family No. 8, where the grandmother even those days represented a positive role model for reading for the mother. She had lead her daughter to reading activities from her early childhood and in this unconscious way she had built the mother's interest in and inclination to family reading. Both of them preferred and intentionally lead their children to reading habits. The opposite situation could be observed in the case of three mothers (f. 2, 5 and 9), where a positive relationship to reading habits and a regular contact with books had developed spontaneously, though, reading had not been preferred in the family environment during childhood. Family No. 7 was a specific example, where the mother's reading role model in her childhood and those days had been represented by her grandparents who, even at an older age, enabled the child and its mother a contact with books from their large family library, which they had built in the early years of their marriage. It is them who, by their reading culture, had inspired and motivated the mother to read books and it had had an impact on her child as well. On the other hand, we consider important to mention the impact of the grandmothers' (f. 6 and 8.) and mothers' (f. 1 and 3) profession of a teacher, their intentional promotion of the development of children's reading competencies, and the effective promotion of their reading literacy as one of the key competencies for the future development of a child. In one case (f. 1), with the grandmother as a reading role model, the element of bilingualism was present. The grandmother read the child books for children in German only (not in Slovak), so she enabled the child a contact with German words in a natural way and gaining knowledge in a foreign language at pre-school age. 


\section{Acta Technologica Dubnicae \\ volume 6, 2016, issue 2}

The language and the verbal expression of a child are determined by the age of the particular family members that the child spends his/her free time after coming home from the kindergarten with. From the responses of the mothers and their children, we have found out that children living in a family environment where the age of the family members, parents, children and siblings was in agreement with the situation in traditional families, i.e. where there were no large age differences between the parents, between the siblings and between the mother and the child, children preferred and used traditional verbal expressions typical for their stage of development. In two cases (f. 1 and 2), children were growing up exclusively with adults, as their mothers had had children at a later age. In their responses, we noticed some untraditional verbal expressions, they were using foreign words and phrases typical for adults. The mothers pointed out the fact, that their close environment perceived their children as 'too smart', differing from their peers. Besides the family environment, kindergartens were found irreplaceable as for the development of children's reading literacy, they promoted it also by visiting local libraries (f. 1 and 6), reading books and making up various stories with children. Both the parents and children considered these activities very important in kindergartens (f. 2, 4, 9 and 10). The mothers (f. 4 and 10) with no inclination to reading activities saw the kindergarten as a substitute role model for reading. According to the opinion of these mothers, it was the kindergartens' duty to form children and to lead them to building of a positive relationship to books. We noticed a tendency of these mothers not to recognise the importance of the presence of a parental role model for children in the process of developing their reading literacy. The joint family reading was realised in the context of going to sleep in every participating family, and, by the mothers, it was considered to be a kind of a family ritual transferred from generation to generation. They saw the function of the joint reading with children before they go to sleep in strengthening the mutual parentchild relationship, creating a calm atmosphere and mutual closeness. One of the mothers (f. 1), saw the time before sleeping as "a part of a day when the child's mind and creativity should not be disturbed by any impulses".

The fathers did not take part in reading activities, two families (f. 2 and 7), were an exception, where in the first case, the father made up his own stories because, according to him, when reading the same story from a book repeatedly, we support an uncreative development of children. The mothers highlighted the function and the importance of the fathers' dramatization during the joint reading with children. Such a dramatization on the side of the fathers was expected by children, too. The mothers showed satisfaction with the presence of the father as one of the factors that influence the development of children's reading habits. The mothers explained the absence of fathers during the joint reading with children by poor reading habits of men in general. 


\section{Acta Technologica Dubnicae \\ volume 6, 2016, issue 2}

\section{1. 2 The place of books in families}

In all the participating families, we registered the presence of books. Their importance was perceived by the mothers variously. The exclusive presence of books for children was evident in families where the parents showed no inclination to reading activities and where the parents were not active and regular readers (f. 4 and 10). Based on the responses of the mothers from the particular families, we can assume that, on one hand, the mothers recognised the need for developing a positive relationship to reading and the need for model situations, on the other hand, they did not do these activities. Neither of the two mentioned families had a family library, but the children had their own libraries. The independent choice of books that a children wished to communicate with, when reading with their mothers, was characteristic for all the families, while, in their responses, the mothers called for books appropriate to the age of children. We registered the children's interest in books in all the participating families, what was confirmed by the mothers' responses as well. The participating children perceived books as toys that attracted them by their visual components and helped them to fill their leisure time. The mothers accentuated the children's high level of curiosity in general, including the field of activities done by mothers. It was the children's curiosity and spontaneous interest that was seen by the mothers as the characteristic feature that could be supported and applied regularly to promote the development of knowledge, lexicon and reading skills in family environment. During the interviews, a new semantic category 'tough times' was created; it was perceived by the mothers from two aspects. From the first aspect, the mothers saw the difficulty of the situation in the context of parents' lack of time, because they had to fulfil more and more demanding requirements, which was reflected in higher requirements on children and their progress, too. They recognised the social changes and the changing requirements on children compared to times, when they had been children. The mothers saw the 'toughness' regarding the requirements on school results, which had been transformed into school documents, textbooks and various educational materials in Slovakia. From the second aspect, they saw the difficulty in the context of changes in storybooks for pre-school age children and in the topics prevailing in these books. The mothers in their responses, on one hand, evaluated traditional Slovak folk tales that they knew and possessed form their childhood positively, on the other hand, when reading together with their children, they were preferred only in three of the families (f. 1,5 and 8). Their quality was seen in mediating the traditional way of life, the surrounding world to children, and in mediating some positive educational elements, from which children could learn moral and ethical values. In the responses of all the participating mothers, we observed the preference of family stereotypes in bringing up children, but also in buying books and the subsequent choice of books for the joint reading. In the mothers' responses, we found a whole scale of prejudice regarding what should girls and what should boys read, i.e. different gender approach, which is considered to be 


\section{Acta Technologica Dubnicae \\ volume 6, 2016, issue 2}

fixed and relatively proven especially in the case of books for child readers. Their existence is undeniable.

In the responses, we found a tendency of children to develop a positive relationship to certain books, which was reflected in an increased frequency of reading the same book during the joint reading as a part of family rituals and activities. Besides traditional books for pre-school age children, some of the mothers (f. 1, 9 and 10) pointed out the positive aspects of interactive books that they were reading with their children. Their efficiency was, above all, understood in the sense of increasing a child's interest in working with books and a better understanding of the text.

In the given field of questions, based on subjective responses obtained from the mothers, another semantic category 'children's contact with books' was formed, as some of the mothers (f. 2, 3 and 6) found it necessary for children to realise the place and the importance of books in the society, their impact on their future, and, at the same time, to appreciate books.

\section{1. 3 The process of reading}

In this set of questions, in this semantic category, we paid attention to the fact whether the mothers and their children understood the complexity of the process of reading and in what context they were able to define reading literacy. Although, none of the children from the participating families could read, we identified a spontaneous interest in the letters of the alphabet in case of all the children. The children were aware of the fact that letters formed certain text structures bearing information. They did not recognise letters only in the context of books, but they were able to identify letters in their environment. The participating children were not able to differentiate between individual letters, with the exception of those in their names. Children knew neither the techniques of reading nor writing, but despite this fact, we did notice an increased interest in letters and in the process of reading. They identified themselves as readers and saw themselves in the role of 'adults'.

The mothers, from this aspect, agreed that children as child readers were not capable to fully recognise the differences between fiction and reality in storybooks, but they observed children's identification - personification with their favourite storybook characters. Only one mother (f. 1) was of the opposite opinion, she intentionally mediated reality when reading fairy tales, by which she accelerated her child's natural development of the perception of fiction. Based on the responses, we can assume, that the process of reading itself was most frequently perceived by children in the context of one's literacy and the acquisition of necessary information (f. 1, 3, 4, 6, 7, 9 and 10). The children realised that texts bore some kind of information and the 'ability to read' was 


\section{Acta Technologica Dubnicae \\ volume 6, 2016, issue 2}

crucial for the development of one's personality; as children said it - "for not being stupid". The similarity in the perception of the process of reading with the previous assumption could be seen in the case of one child (f. 5), who saw the knowledge of the process of reading as a determinant of one's job opportunities. Another point of view was offered by a child (f. 2), who understood the process of reading in the context of the joint reading before falling asleep with the function of a lullaby and his/her unfamiliarity with written text and the techniques of reading. The child did not see a deeper meaning in the process of reading. In this case, we noticed the child's fixation on the regular joint activity with his/her mother, i.e. on reading before falling asleep, that represented a regular ritual in the particular family. Some of the mothers (f. 1, 2, 3, 4, 7, 9 and 10) considered elementary schools to be crucial for the development of the active process of learning to read and write. We could identify some kind of children's 'protection' from reality on the side of the mothers - which their children could not read or write before entering elementary schools. We observed a targeted promotion of the children's process of learning to read and write before entering the school environment only in one case (f. 8). That mother had recognised the challenges of the child's school progress and success in the future, therefore she was intentionally leading the child to an active process of reading and acted as a positive role model for reading. This way the child had been gradually building knowledge about individual techniques of reading. When inquiring information regarding the understanding and perception of reading literacy as one of a person's key competencies, in the responses of the mothers, we identified the existence of knowledge and information from the given field. In three cases (f. 2, 3 and 9), the mothers were familiar with the term reading literacy from the media, as it was used in the context of the results of Slovak pupils in testing their reading literacy as a part of international studies PISA and PIRLS, while in one case (f. 3), the knowledge of the mother could be related to her pedagogical profession. The mothers from the participating families mostly defined the notion of reading literacy in relation to the need for reading comprehension, they accentuated the necessity of checking reading comprehension during the joint reading with children. Some weaknesses in defining this notion were found in the mothers' responses in two families (f. 4 and 10), where the mothers did not incline to reading activities and had not developed a positive relationship to regular reading of books. These mothers put reading literacy into relation with lay understanding of the gradual development and improvement of reading and writing skills, and, at the same time, in connection to children's school success.

\section{1. 4 Accompanying activities}

In some sets of questions, we focused our attention on the diversity of the accompanying activities applied and realized in a particular family environment in relation to joint family reading with the child to promote its creativity, 


\section{Acta Technologica Dubnicae \\ volume 6, 2016, issue 2}

imagination, thinking and the development of the child's lexicon. For a child at pre-school age, working with a book is a game. It is a natural activity by which a child can learn about many things and phenomena. Fairy tales, various creative stories and reading books represent a precondition for uncovering children's skills and knowledge. In all the participating families, from the aspect of the mothers' initiative, but also from the point of view of children, we identified various activities promoting children's reading literacy. In some of the families, a joint discussion about the read was the most frequent accompanying activity during the joint reading with children, while questions about the read were applied by mothers as a diagnostic tool of the comprehension of the story. The mothers declared the need for getting feedback from the child with the purpose of getting information about the child's concentration on the read text and its comprehension. The mothers were the initiators, they were asking targeted questions about the read text in most of the participating families (f. 1, 2, 4, 5, 7, 8,9 and 10). In two cases (f. 3 and 6) we found out that the discussion about the story read was led by children by means of spontaneous reflection on and description of storybook characters that the children identified with. The mothers in these families insisted on monitoring the suitability of books for children, while in three cases (f. 1,9 and 10) we observed creative work with interactive books, which, as containing various additional components evoking children's curiosity, enabled children to discover the surrounding world in a playful way and naturally influenced children's thinking and creativity.

In the children's responses, we identified an increased interest in interactive books. We can assume that joining the visual and auditory elements of books helped children at pre-school age to understand the read text better, and, on the other hand, increased the children's interest in books containing tasks and, thus, giving them the opportunity to complete some elements creatively. In this case, we can point out the function of children's fine motor skills improvement. A specific example of working with books was presented by the mother (f. 9), who intentionally transferred knowledge to her child in cases when he/she misbehaved. It was in agreement with the plot of the fairy tale with the aim to give him/her a lesson and to distract his/her attention from inappropriate behaviour. Other creative activities that mothers did with their children were those focused on making up and finishing stories. In three cases (f. 5, 6 and 7) we could see examples of adding text to picture stories. From the subjective responses of the participating mothers and their children, we learned about some oral interactive activities when working with books in families (f. 1, 2, 3, 7, 8 and 9). The character of the realised activities contributed to the development of reading literacy and literacy in general. The highest degree of creativity on the side of the mother could be seen in one case (f. 7), where the mother intentionally promoted her child's fantasy and creativity by means of visual art after reading a fairy tale, she instructed the child on visualising his/her thoughts. 


\section{1.5 Visual components}

When collecting the responses and the evaluation of questions focusing on the perception of individual visual elements in books for pre-school age children and on children's perception of the visual aspect of books, we received clear, almost not differing responses from the mothers and their children. We could see an agreement in the responses of both children and their parents regarding eyecatching book covers for children and books in general, too. It was considered to be the basic criterion of selection. In the responses of the participating children, we identified the presence of gender stereotypes in the process of choosing books, and their preference on the side of the mothers. In the in the children's responses we observed an agreement regarding the requirement for the presence of illustrations in storybooks. Pictures were decisive for child 'readers', which was emphasised by them. In some cases, (f. 2, 3, 6 and 8), the differentiating factor between the books for children and books for adults was the presence of colourful pictures in children's books and their absence in books for adult readers, that were characterised by children as uninteresting. One child (f. 1) strongly refused the presence of pictures in books for adult readers reasoning that they could read and write and, therefore, they did not need any pictures. In some of the participating families (f. 2, 3, 5, 7 and 8), the parents practised the so-called 'picture reading' with their children, when the child constructed and completed the story depending on his/her understanding of the read text and the pictures. The details of the pictures helped the child to construct his/her own plot and using this method he/she got into the role of an independent reader. In the participating families (f. 1, 2, 3, 4, 5, 6, 7, 9 and 10), children were able to retell a story meaningfully, and it was possible to identify the storybook characters, the plot, the beginning and the end of the story. The absence of the plot, beginning and the end of the story and of a brief description of individual pictures in the book could be noticed in the case of one child (f. 8). Two of the mothers (f. 3and 5), from this aspect, pointed out the need for 'more detailed' pictures in children's books, that could support children during the joint or 'independent reading', and, at the same time, help parents in the creative construction and making up new stories. Regarding the perception of the visual components in books for children, the participating children (f. 1, 2, 3, 4, 9 and 10) when manipulating with a children's book, demonstrated knowledge of some print conventions. Though, the children did not know the process of reading, we identified the children's correct manipulation with books - turning the pages, holding the book, reading from up to down and from left to right. The children knew the title, the author and the numbers of pages in the book. The requirement for illustrations in books, their colourfulness, was present in several families (f. $1,3,4,8$ and 10), where the mothers pointed out the need for a larger size of books and of their visual components, and they suggested to apply real life stories with the intention to mediate children some basic information for life in 


\section{Acta Technologica Dubnicae \\ volume 6, 2016, issue 2}

the society, information necessary for achieving school maturity, and with the intention to help children when entering the school environment. Three of the participating mothers (f. 2, 8 and 10) preferred commercial books by foreign authors that contained large colourful pictures that were eye-catching for preschool age children.

\subsection{Perception of the process of family reading by pre-school age children in the context of the conditions of family environment}

When inquiring on how the children understood the concept of family reading that appeared and was realised in particular families, we worked with the products of children's visual expression (drawings) in combination with their subjective responses. We gathered information for a better understanding of the concept of family reading in the context of the conditions of the family environment, by which we have contributed to the field of conceptualising the process of reading in family environment from the point of view of child participants in relation to the promotion of children's reading literacy in families.

All the drawings collected from the participating children told us about the situation of family reading in which the children acted as the main characters. When trying to identify the places where reading took place in the drawings, they varied. The child's own bedroom was depicted as the place of reading in five drawings only (ch. Kristína, Rebeka, Amália, Tomáš, Daniela). Children saw their rooms as a place where they liked to spend their free time, they had all their toys, books and furniture. As we saw again, gender stereotypes where applied in the choice of the colours of furniture for girls and for boys. In some of the drawings (ch. Alexandra, Anna, Lukáš, Matej) we identified the outer environment (court, garden, the place in front of the front door) as the place for reading - these families lived in family houses. These children had enough opportunities for meaningful spending of their leisure time in the fresh air in the nature and such activities were supported by their parents, too. In one case (ch. Simona), the child depicted family reading in her parents' bedroom. She understood family reading as joint reading before going to sleep, which was a ritual in her family. Children were portrayed as independent 'readers' in the drawings of three of the participating children (ch. Kristína, Amália, Matej), which corresponded with the interview results where we found out that their mothers did not promote reading habits in family environment. The drawings displayed the children as independent readers widening their knowledge by making up their own stories depending on the fact, how they understood the pictures in the book. These children expressed their own interest in reading activities with books in their drawings and the absence of parents and their help when reading a storybook. The pleasure of making up stories based on pictures could be seen in the drawings, too, there was a smile on the faces of the readers. 


\section{Acta Technologica Dubnicae \\ volume 6, 2016, issue 2}

In one case (ch. Kristína), the drawing contained some abstract elements. It was a proof of the child's creative approach. She displayed the storybook as "magic" and "flying" in the room. We can explain the child's creative thinking processes by her preference of the joint interactive activities of the mother and the child, e.g. the joint writing of poems and songs. The mother, in this case, did not insist only on reading books to her child to promote the development of her reading literacy in the family environment. The beginnings of abstract thinking could be seen in one child's drawing (ch. Anna). She was able to display then abstract elements of the 'big magic book'. An interesting way of portraying parents was present in one child's drawing (ch. Matej). Their presence was not perceived by the child in the context of the joint reading, but in the context of everyday running of the household. The child registered the presence and acting of his parents who were his role models. In the drawing, he showed objects to which he had developed an emotional relationship. The presence of a dog reflected the need for a substitution for the absence of a parent when reading books. In the rest of drawings (ch. Rebeka, Alexandra, Tomáš, Anna, Simona, Daniela, Lukás), one of the parents was present during the joint reading. The father participated only in one case (ch. Simona), everywhere else mothers were present. The child told about the presence of the father during the joint reading by means of visual expression. She expected her father's dramatization of the text during reading the story, his creative expression that the child liked and preferred the joint reading with her father to reading with her mother. We can see the contribution of dramatization when reading fairy tales in promoting the development of imagination and children's lexicon, and in a creative expansion of the children's world of experience. The presence of the mother during the joint reading was evident in six drawings (ch. Rebeka, Alexandra, Tomáš, Anna, Daniela, Lukáš), which corresponded with the responses of the mothers and the children regarding joint reading activities preferred in particular families. The mothers were displayed close to the children, which means, that the children received help and support from their mothers in the process of early reading literacy development. In two cases (ch. Rebeka, Daniela), the drawn characters were of the same size and the book was placed between the mother and the child. That way these children put themselves in the role of equal partners during the joint reading.

At the same time, in some drawings (ch. Rebeka, Daniela, Alexandra, Anna), children portrayed themselves as their mothers' copies, which is a proof of their inclination to their mothers as role models for behaviour, acting and reading activities. The most frequently drawn products for reading were storybooks; they were preferred by the families during the joint reading because children liked them. This fact corresponds with the responses of children regarding their interest in particular books. The existence of own library was depicted in two of the drawings (ch. Rebeka, Tomáš), while, in the first case, it had a central 


\section{Acta Technologica Dubnicae \\ volume 6, 2016, issue 2}

position in the picture. By means of drawing, the children showed the quantity of children's storybooks in their family environment and their relationship to them. In three of the drawings (ch. Kristína, Amália, Simona), the doors of the rooms were closed, expressing children's need for privacy during practising reading habits, and, at the same time, the feeling of safety and security in their family environment. The children were aware that every book contained a different story. They were able to express it by using different colours for different books. The position of the book in the drawing was emphasised by detailed lines (ch. Kristína, Rebeka, Amálka, Tomáš, Anna, Daniela, Matej), while in three cases (ch. Kristína, Anna, Matej), we identified the presence of letters in books as elements of literacy reproducing the text bearing information.

In our study, we have already pointed out that the children demonstrated knowledge of some letters in the context of the letters that their names consisted of. Though, the participating children did not know the techniques of reading or writing, they were able to recognise letters and text. One child's drawing (ch. Anna) contained a coherent text entitled "Welcome to the magic book". The child's interest in writing letters was demonstrated by asking an adult to write the text that was, subsequently, retraced by the child.

In the detailed parts of the drawings, with regard to the main theme, i.e. perception of the process of family reading by pre-school age children in the context of the conditions of their family environment, the real situation of family reading in particular family environments was reflected by children.

\section{Discussion and conclusions}

We interpret the research on a qualitative level. The results are based on the obtained information from the field of developing reading literacy in family environment. Therefore, we do not compare the results obtained in particular families, but we present general conclusions that we have come to in our research. The results show that family reading and the development of children's early reading literacy depended on the mothers' approach to reading habits and on how important the process of reading they considered to be. Also the mothers with no inclination to reading habits were aware of their function as an indicator of reading literacy development of their children as early as at pre-school age. The joint family reading of mothers with children was realised in families with pre-school age children in a various frequency and depth, mainly in the evening in the context of going to sleep, what was perceived by the mothers as a certain family ritual. At the same time, they pointed out the function of reading with children before falling asleep for strengthening their mutual relationship and for the development of children's lexicon. The mothers were not satisfied with the insufficient participation of the fathers in the joint reading with children. We can 


\section{Acta Technologica Dubnicae \\ volume 6, 2016, issue 2}

declare that the way the mothers practised activities related to reading with their children and regulated the children's tendency to read, was influenced by the model of promoting reading literacy and the approach to reading in general that had been applied by their parents (i.e. by the grandparents of the participating children), which was confirmed by the mothers' responses. In the field of the targeted action on the side of the family members in the process of early literacy development of pre-school age children, the mothers and their children confirmed a strong impact of grandparents in promoting children's reading. The mothers used tough times, heavy workload and busyness related to the role of a mother as excuses for the insufficient realisation of reading activities with children. These were perceived as the basic determinants influencing the lack of time for the joint reading with children on the side of the mothers and the subsequent need for the presence and help on the side of the grandparents in bringing up their grandchildren and in promoting the development of children's reading literacy. A positive role model for reading for children was represented by kindergartens, which realised activities focusing on listening to stories, understanding them and evoking an emotional interest; and, thus, prepared children for entering the school environment effectively. We can assume that the mothers considered forming and leading their children towards the development of a positive relationship to books to be the duty of kindergartens.

When inquiring on the position of books in family environment we noticed the presence of books and family libraries in families. In families with no inclination to reading habits, we observed the exclusive presence of books for children. The parents were aware of the need for children's contact with books when learning about texts, letters and pictures even at pre-school age; they perceived it in the context of children's spontaneous interest in books that was confirmed both by the parents and the children. During the interviews, we found out that the mothers preferred the children's independent choice of books for joint reading activities. They monitored the suitability of the chosen books from the point of the age of children, by which they supported the development of children's personal predispositions. In this way they worked with the children's natural and spontaneous interest in books. On the other hand, we observed the existence of gender stereotypes in choosing books for reading by children. It might be rooted in the presence of gender stereotypes in the everyday life of families.

The mothers preferred interactive books during the joint reading with children, they saw their efficiency mainly in increasing children's interest in working with books and helping to understand the plot better. In this context, they emphasised how difficult it was to buy a suitable book for children. They saw the main deficiencies of books for children in unclear text, obscure pictures, and the American impact on the themes for children and on the visualisation of books, which might lead to parents' disability to explain stories from other cultures. 


\section{Acta Technologica Dubnicae \\ volume 6, 2016, issue 2}

By an analysis of data with the aim to answer our research question focusing on the perception of the process of reading in the context of the issues of reading literacy by the parents and their children, we received clear answers. Children, before entering the school environment, demonstrated a spontaneous interest in letters. They knew that letters were a part of certain text structures that bore information. At the same time, they were not able to differentiate between the letters, but the children's fixation exclusively on letters that their names consisted of could be observed. Although the children could not read, they demonstrated their own understanding of the process of reading, especially in the context of one's literacy, getting information necessary for life, but also in the context of the necessity of being able to read and write. This was perceived as one of the conditions for getting job opportunities. The children connected the ability to read with feeling 'adult' and they recognised their independence in the acquisition of information. Children's interest in the process of reading could be observed in their prevailing desire to interchange the roles of the reader and the listener during the joint reading with their mothers. In the given field, the mothers' knowledge on the issues of the perception of reading literacy was important. They defined it in relation to the results of Slovak pupils in testing their reading literacy within the international studies PISA and PIRLS presented in the media. They perceived it in connection with the need for reading comprehension. They emphasised the need for feedback from children both when checking understanding of the text read and during the joint reading with children at pre-school age. It helps to avoid mechanical reading on the side of children in the future. On the other hand, we can point out lay understanding of reading literacy by those mothers, who were not fond of reading habits in family environment. They perceived it in connection with the requirement for developing children's ability to read and write. As they said, it had been related to the later school success of children.

The next research question dealt with the intentional and unintentional impact of parents on the development of children's early reading. It was focused on the ways of developing children's lexicon and improving their understanding of the heard or read text from the point of view of the mothers and their children. We identified a wide range of activities promoting children's reading literacy. A discussion about the story was the most frequent accompanying activity by the joint reading when the mothers were asking questions to satisfy their internal need for finding out, if the children had understood the read story. This way they got feedback from the child and information on if the child paid attention to the read text. The mothers practised activities during which they were making up and completing stories based on pictures and, thus, helped children to understand the concept of a picture as the carrier of particular information. They inspired children to independent 'picture reading', by which a child could gradually get into the role of a reader and learn about the concept of printing books. Based on 


\section{Acta Technologica Dubnicae \\ volume 6, 2016, issue 2}

the results, we can state that there was an increased frequency of using interactive books when working with children in families, we observed a spontaneous interest in them. On one hand, most children inclined to books with auditory elements that enabled a better understanding of the read text through joining auditive and visual elements. On the other hand, children liked books where, thanks to task based activities, they had the opportunity to complete some elements creatively. These activities were improving children's fine motor skills as well. In their responses, the mothers and their children accentuated the contribution of using various interactive activities when working with books and spoken language (joint recitation, rhymes, singing, making up rhymes, verses, poems, activities related to visual expression - retracing pictures in books, the letters of the alphabet, drawing pictures after reading a story, drawing storybook characters that the children had identified with, etc.). Such activities, by their character, contribute to the development of reading literacy and literacy in general.

The clear responses of almost all the mothers and children allowed us to answer our next research question focused on the perception of the visual components in books for pre-school age children, and on children's perception of the visual aspect of books. It is the visual aspect of books for children, their colourfulness, and the presence of a variety of illustrations that the mothers find the most important criterion when choosing a book. There is a tendency of children to incline to a certain type of storybooks. In this context, we can point out the existence of children's gender stereotypes when choosing a book and their enforcement on the side of the mothers again. At the same time, children accentuated the necessity of the presence of pictures in children's books, what is more, they considered them to be the distinguishing factor between the books for child readers and the books for adult readers. During our research, we observed so-called 'picture reading', where pre-school age child 'readers' were able to construct and complete meaningful stories depending on their understanding of what was in the pictures and in the text read - they took the role of independent readers. In this context, the mothers accentuated the need for a larger number of detailed elements in pictures that would help to grasp the child's attention and perception during the repeated joint reading with the mother. Despite children did not know the process of reading at pre-school age before entering the school environment, they demonstrated knowledge of some print conventions, they knew how to manipulate with books, how to turn the pages, hold the book, to read from up to down, from left to right, they knew the title of the book, it's author and page numbers. The mothers considered a larger size of books for children, their visual components and the colourfulness of books the basic features of suitable books for pre-school age children, and suggested to include real-life motives with the aim to get basic information for life in the society and 


\section{Acta Technologica Dubnicae \\ volume 6, 2016, issue 2}

information for achieving school maturity, too. It should help children when entering the school environment.

Our research dealt with the issues of children's reading literacy from the aspect of an unsystematic stimulation on the side of the literal family environment. The results of this research may represent a contribution to a further extension of knowledge in the field of reading literacy in the context of family environment and effective development of reading literacy as soon as it begins to appear at pre-school age. We gained the results based on the experiences of children and their parents who were involved in our research. At the same time, we assume that despite the limits of a qualitatively oriented research regarding the impossibility to generalise the research findings, our results will offer inspiring suggestions for further research questions.

\section{References}

Barnová, S. (2010). Sociálne aspekty školy z pohladu resiliencie. Dissertation, Katedra pedagogiky PdF UK. Bratislava: Univerzita Komenského v Bratislave.

Chandler, K. (1999). Home literacy activities and aigns of children's emerging literacy. In National center for education statictics. Washingtion, DC: US Department of Education. Retrieved from http://nces.ed.gov/ pubs2000/2000026.pdf

Dobbs-Oates, J., Pentimonti, J. M., Justice, L. M., \& Kaderavek, J. N. (2015). Parent and child attitudinal factors in a model of children's print-concept knowledge. Journal of Research in Reading, 38(1), 91-108.

Fisher, D., \& Frey, N. (2014). Speaking and listening in content area learning. The Reading Teacher, 68(1), 64-69.

Fitzgerald, J., Spiegel, D. L., \& Cunningham, J. W. (1991). The relationship between parental literacy level and perceptions of emergent literacy. Journal of Reading Behavior, 23(2).

Gavora, P. (2007). Sprievodca metodológiou kvalitatívneho výskumu. Bratislava: Univerzita Komenského v Bratislave.

Glazer, S. M. (1989). Oral language and literacy. In D. S. Strickland, L. M. Morrow et al., Emerging Literacy: Young 16 Children Learn to Read and Write (pp. 16-26). Newark, Delaware: International Reading Association.

Kissinger, A. M. (2004). The need for emergent literacy events in schools. Knowledge Quest, 33(2), 58-60.

Maclean, M., Bryant, P., \& Bradley, L. (1987). Rhymes, nursery rhymes, and reading in early childhood. Merrill-Palmer Quarterly, (33), 255-81.

Montero, M. K., Newmaster, S., \& Ledger, S. (2014). Exploring early reading instructional strategies to advance the print literacy development of adolescent SLIFE. Journal of Adolescent \& Adult Literacy, 58(1), 59-69. 
Moss, B., \& Fawcett, G. (1995). Bringing the curriculum of the world of the home to the School. Reading \& Writing Quarterly: Overcoming Learning Difficulties. (11), 247- 256.

Pazonyi, J., \& Bodonyi, E. (2013). Developing language literacy in the educational scene. Acta Technologica Dubnicae, 3(2), 36-47.

Snow, C.E. (1991). The theoretical basis for relationships between language and literacy in development. Journal of Research in Childhood Education, (6), 5-10.

Strickland, D. S. (2004). The role of literacy in early childhood education. The Reading Teacher, 58(1), 86-88.

Tamášová, V., \& Šuverová, S. (2008). Práca s rodinami ako partnermi pri získavaní ranej gramotnosti detí. In Lingvistické a didaktické aspekty cudzojazyčnej prípravy v komerčnej sfére (pp. 56 - 64). Bratislava: Lingos.

Zápotočná, O. (2011). Rozvoj jazykovej gramotnosti na základnej škole. Trnava: Pedagogická fakulta Trnavskej Univerzity v Trnave. 